\title{
Endoscopic Endonasal Odontoidectomy: Nuances of Neurosurgical Technique
}

\section{Odontoidectomia endoscópica endonasal: nuances da técnica cirúrgica}

\author{
Flavio Ramalho Romero ${ }^{1}$ Rodolfo Brum Vieira ${ }^{1}$ Bruno da Costa Ancheschi ${ }^{1}$ \\ ${ }^{1}$ Department of Neurosurgery, Universidade Estadual Paulista Júlio \\ de Mesquita Filho, Faculdade de Medicina Campus de Botucatu, \\ Botucatu, SP, Brazil

\begin{abstract}
Address for correspondence Flávio Ramalho Romero, MD, MSc, PhD, Universidade Estadual Paulista Júlio de Mesquita Filho, Faculdade de Medicina Campus de Botucatu, Botucatu, SP, Brazil
\end{abstract} \\ (e-mail: frromero@ig.com.br).
}

Arq Bras Neurocir 2018;37:157-161.

\author{
Abstract \\ Keywords \\ - craniocervical \\ junction \\ - odontoidectomy \\ - endoscopic \\ endonasal approach \\ - transoral approach
}

Odontoidectomy is the treatment of choice for some diseases that cause irreducible ventral compression of the brainstem. In this study, we present our series emphasizing the technical nuances of endoscopic endonasal odontoidectomy.

\section{Resumo \\ Palavras-chave \\ - transição crânio- cervical \\ - odontoidectomia \\ - acesso endoscópico endonasal \\ - acesso transoral}

Odontoidectomia é o tratamento de escolha para algumas doenças que cursam com compressão irredutível do tronco encefálico. Neste trabalho, apresentamos nossa série enfatizando as nuances da técnica cirúrgica da odontoidectomia por via endonasal endoscópica.

\section{Introduction}

Odontoidectomy is the treatment of choice for some diseases that cause irreducible ventral compression of the brainstem. ${ }^{1-3}$ The transoral route has been used for many years as the standard approach to decompress the ventral craniovertebral junction $(\mathrm{CVJ}){ }^{1-4}$ However, this approach is associated with high complication rates involving swallowing and respiratory issues. ${ }^{1-5}$
Alfieri, in 2002, ${ }^{6}$ and Kassam, in 2005, ${ }^{7}$ were the pioneers to demonstrate that the endoscopic endonasal approach is feasible to decompress the CVJ. The first performed an anatomical study, and the second used the endoscopic endonasal approach to treat a patient with ventral brainstem compression due to rheumatoid pannus. ${ }^{6,7}$

Here, we present our series emphasizing the technical nuances of endoscopic endonasal odontoidectomy. received

May 20, 2018

accepted

June 5,2018
DOI https://doi.org/

10.1055/s-0038-1667181. ISSN 0103-5355.
Copyright $\odot 2018$ by Thieme Revinter Publicações Ltda, Rio de Janeiro, Brazil 


\section{Casuistic}

We retrospectively reviewed a prospectively collected database of all patients undergoing fully endoscopic endonasal surgery between 2009 and 2018. From this database, we identified 16 patients (9 female and 7 male) treated by fully endoscopic endonasal odontoidectomy. The diagnoses were basilar impression in eight patients, rheumatoid pannus in six cases, and os odontoideum in two cases. The indication of surgery was based in the irreducible aspects of their conditions and the severity of compression of the brainstem. All basilar impression patients had irreducible subtype A according to the Goel classification, while rheumatoid pannus and os odontoideum patients had very severe brainstem compression with neurological disabilities. All patients had signs of myelopathy, 13 had neck pain (81.2\%), and 6 had swallowing disturbances (37.5\%).

\section{Operative Technique}

After general anesthesia, the patient is placed in prone position with 3-point fixation and routinely receives $2 \mathrm{~g}$ of cephazolin, intravenously. A binostril approach is performed. The middle and inferior turbinates are displaced laterally. Under endoscopic view (0-degree, $17 \mathrm{~cm}, 4 \mathrm{~mm}$ scope), the inferior, middle, and superior turbinates are identified, and the mucosae of the inferior and middle turbinates are injected with a solution of lidocaine $1 \%$ and epinephrine $(1: 100,000)$. The endoscope is gently advanced through the nasal floor to the choana (-Fig. 1).

When the nasopharyngeal mucosa is visualized, it is very important to identify the landmarks. Eustachian tubes are the main references to avoid an internal carotid artery injury that runs posterolaterally, and the Rosenmuller fossae are displaced laterally. The mucosa incision is performed medially to the Eustachian tubes, in a linear shape, over the anterior $\mathrm{C} 1$ tuberculus, advancing upward, until direct skeletonization of the clivus and CVJ is obtained. Lateral and anterior fluoroscopy images or navigation devices should be used to confirm the position. Resection of the anterior longitudinal ligament is needed to access the atlantoaxial articulation. The $\mathrm{C} 1$ anterior arch is removed with a drill and a Kerrison punch in all our cases to have a good exposure of odontoid process. After odontoid exposure, the removal is initiated. The core of the odontoid is drilled out with a diamond drill and the residual shell of the odontoid is removed before cutting the surrounding fibrous pathologic tissue, if present, or sectioning of apical, alar, and cruciate ligaments. The amount of removal depends on the abnormality to be treated. In patients with inflammatory conditions, such as rheumatoid pannus, thickening of the surrounding tissue, including the ligaments, is mandatory to have a good decompression (-Fig. 2).

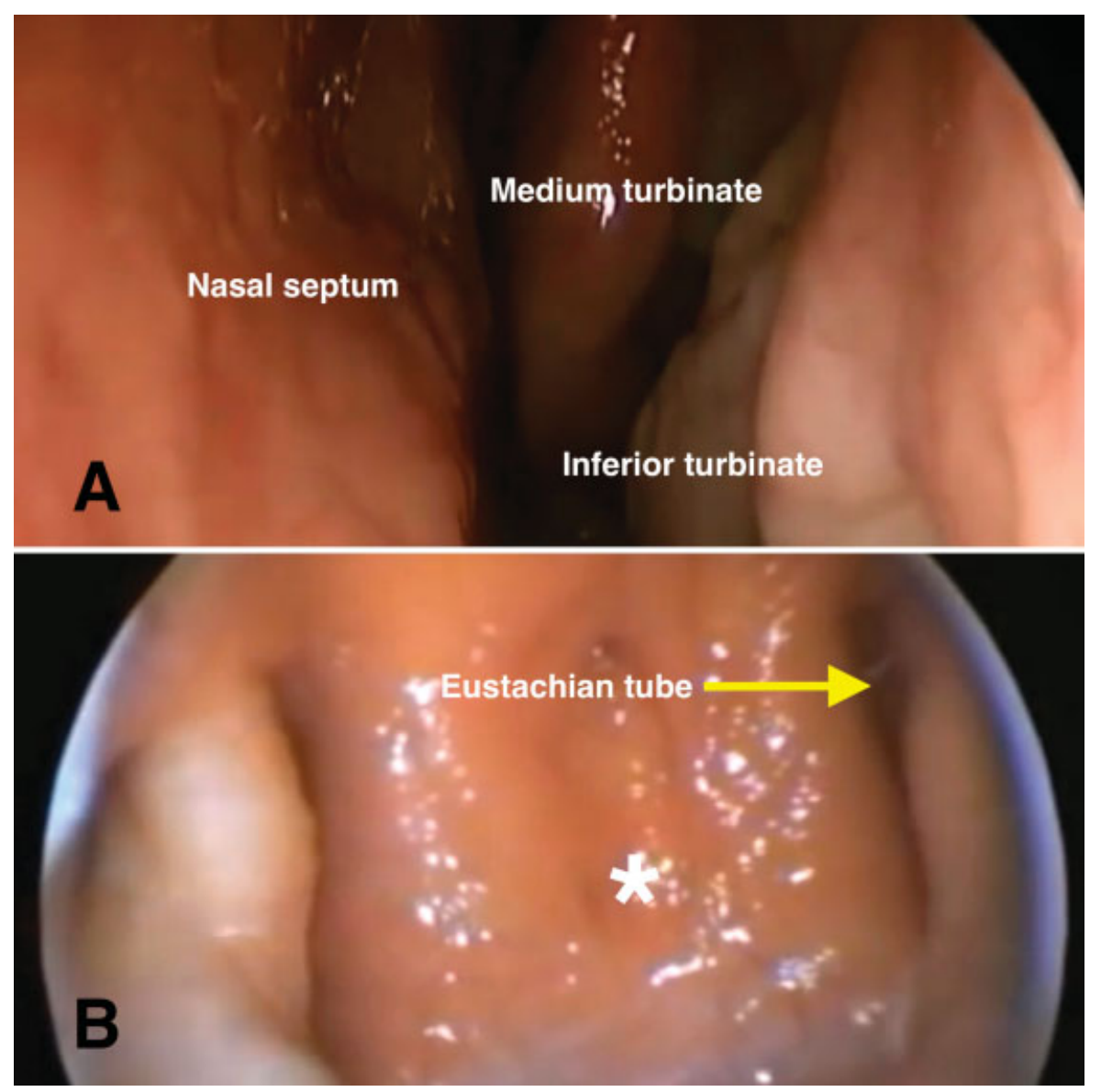

Fig. 1 (A) Nasal cavity inspection showing inferior and middle turbinates and nasal septum. (B) View through the choana of nasopharyngeal mucosa showing the Eustachian tube and the point of mucosal incision $\left(^{*}\right)$. 

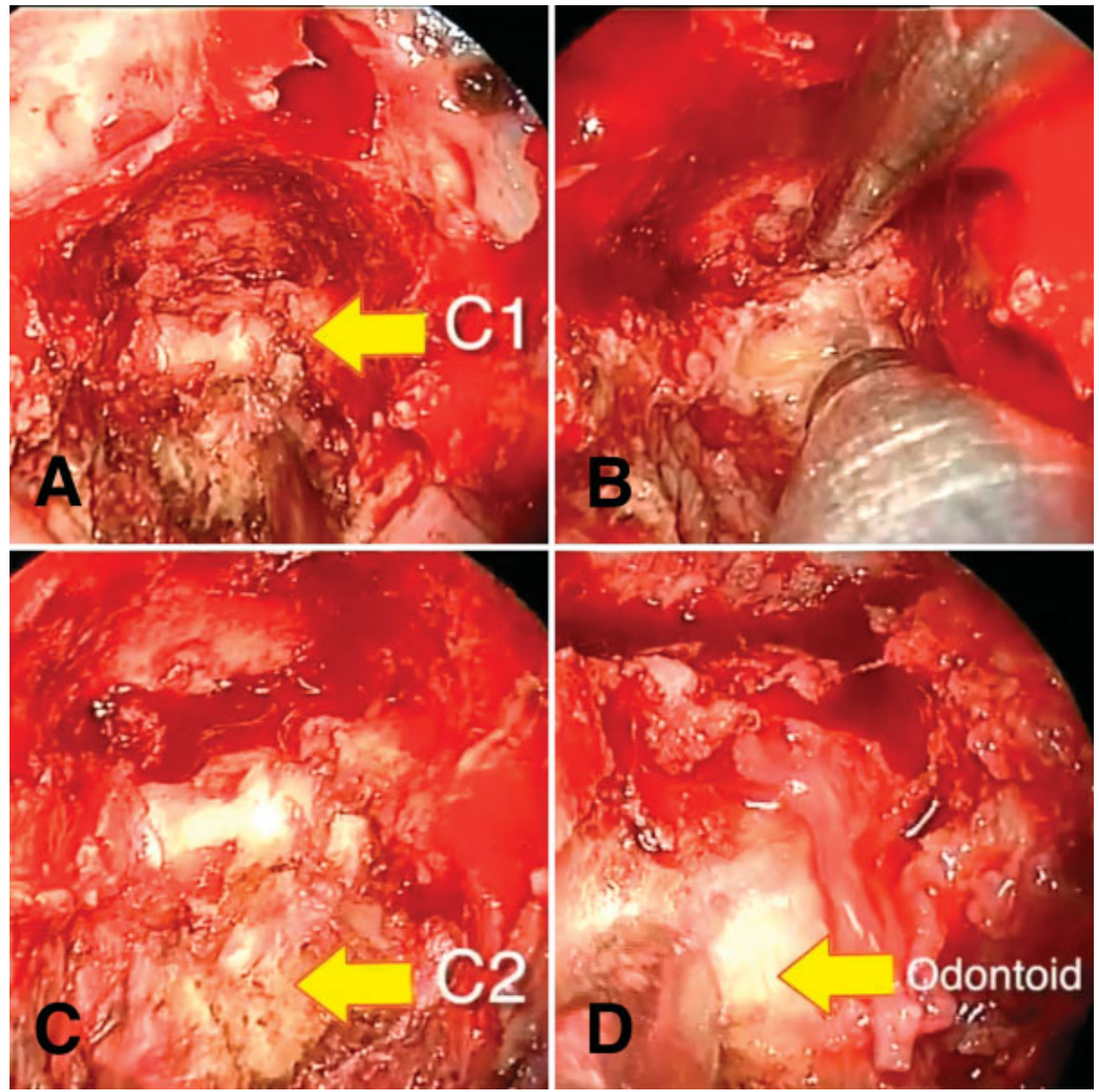

Fig. 2 Craniocervical junction (CVJ) after skeletonization. (A) Arrow indicates C1 anterior arch. (B) Drilling of C1 anterior arch. (C) Arrow indicates ventral C2 body. (D) Arrow shows odontoid process.

Closure is an important step. Cases of cerebrospinal fluid (CSF) leak must be carefully managed. Abdominal fat and dural sealants are routinely used for this purpose, and a 48-hour lumbar drain is placed if CSF leak is present. Then, the nasopharyngeal mucosa is closed, and nasal packing is performed. All patients were placed in ventral position and a occipitocervical fusion was performed.

After the surgery, immediately removal of orotracheal tube and restoring spontaneous ventilation is waited. Talking is allowed in the first postoperative day if no CSF leak is observed. Otherwise, in cases of CSF leak, 3 days of bed rest are required. The nasal packing is removed after 2 days. Also, oral feeding can be resumed in the first postoperative day, and a computed tomography (CT) scan is advised to confirm odontoid resection and rule out early complications (-Figs. 3, 4 and 5).

\section{Discussion}

The CVJ ventral compression remains a challenge for neurosurgeons. Congenital conditions, traumatic injuries, infectious diseases, inflammatory conditions, tumors, or other acquired anatomic lesions may lead to basilar impression of the odontoid onto the brainstem and spinal cord. This

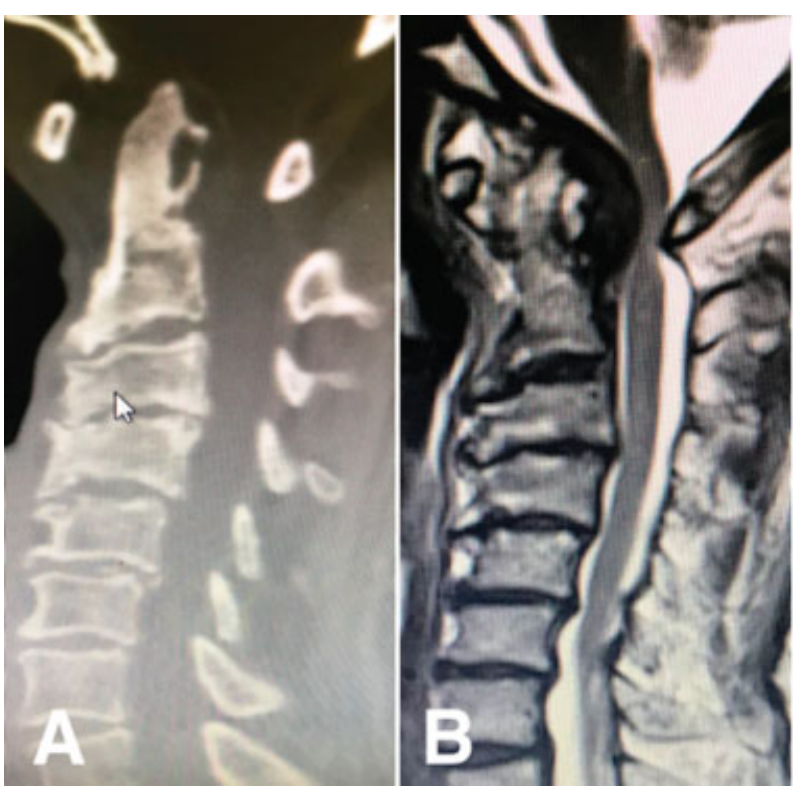

Fig. 3 (A) Preoperative sagittal computed tomography scan. (B) Preoperative $\mathrm{T} 2$ magnetic resonance imaging showing ventral compression of brainstem at craniovertebral junction. 

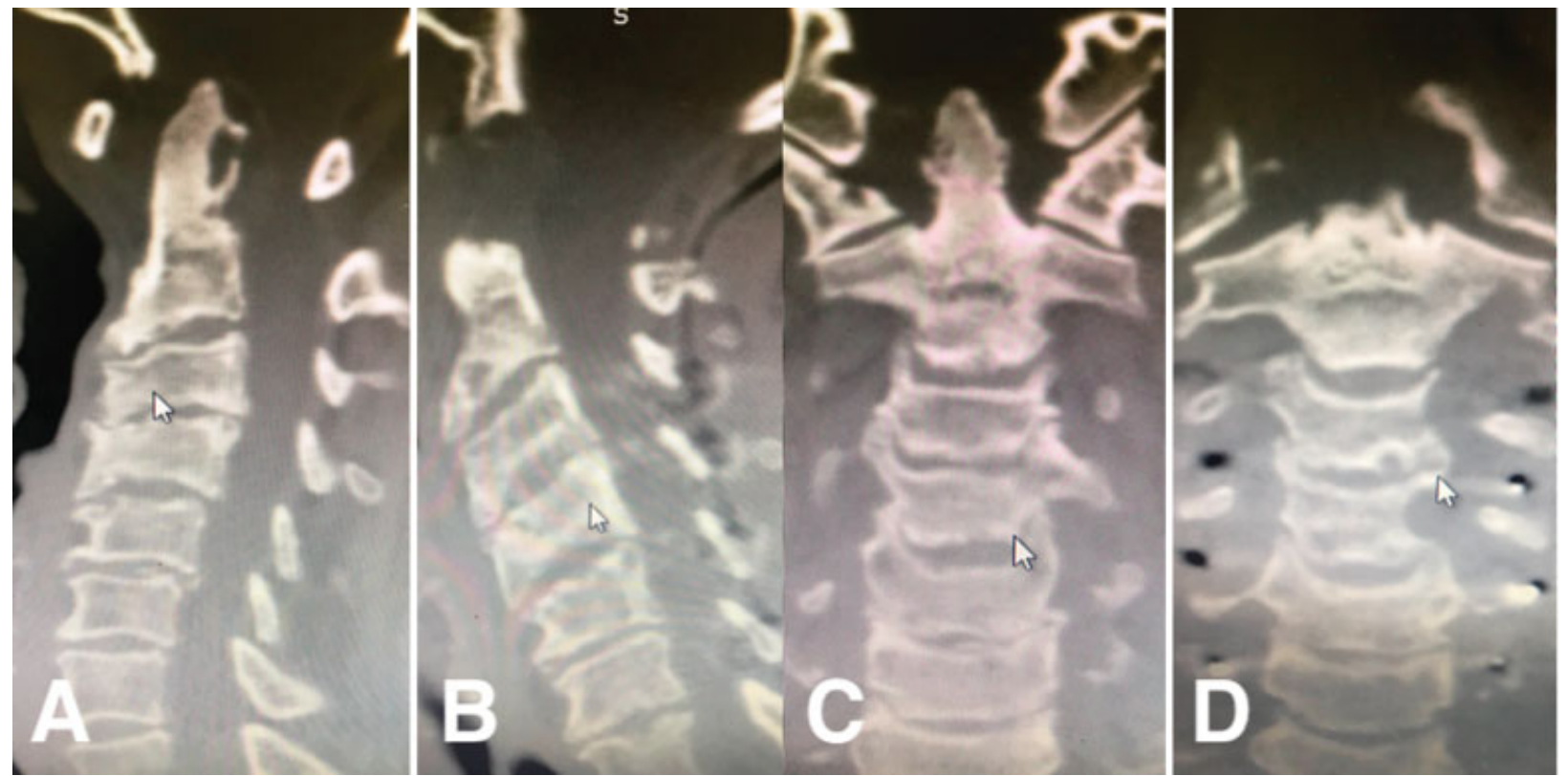

Fig. 4 (A) Preoperative sagittal computed tomography scan. (B) Postoperative sagittal computed tomography scan. (C) Preoperative coronal computed tomography scan. (D) Postoperative coronal computed tomography scan.

compression results in neurologic impairment, most commonly numbness and tingling in the limbs, early on, and later, as the motor nerve weakens, sensitive disturbances, and sphincter control loss. Most of the times, surgical intervention is needed to relieve compression and restore the neurological function. ${ }^{3,5,7,8}$ Our casuistic was basically composed of basilar impression (Goel A irreducible type), rheumatoid pannus and os odontoideum (congenital malformation) cases.

The transoral is the traditional approach used by most of the surgeons and remains as the gold standard for decom-

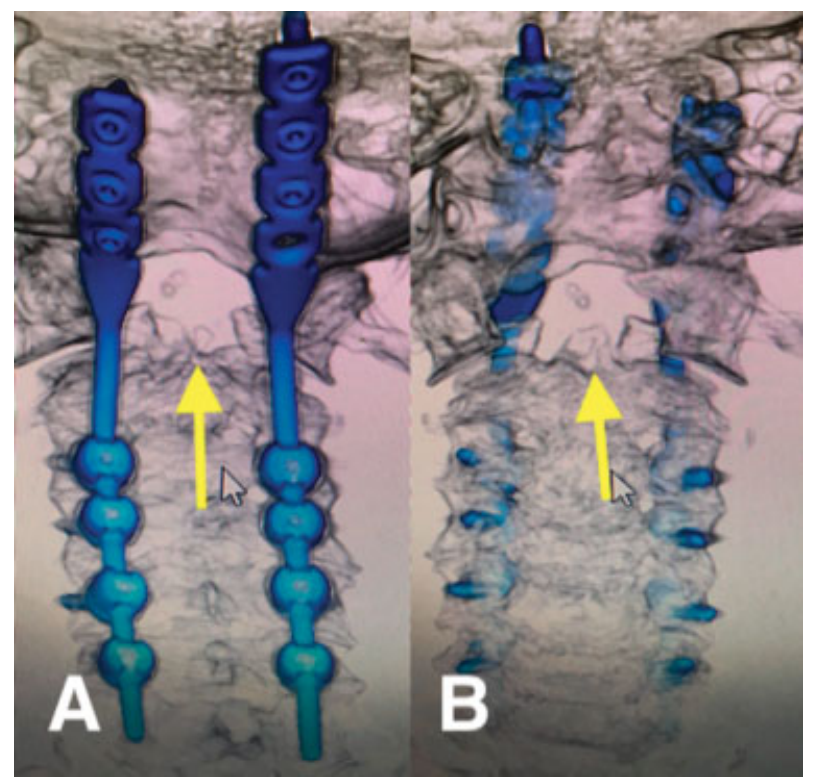

Fig. 5 Postoperative 3D computed tomography scan reconstruction. (A) Posterior view. (B) Anterior view. Yellow arrows indicate the part of odontoid removed. pression of this region. ${ }^{1-4}$ Many authors have reported problems in the postoperative management of these patients, mainly regarding swallowing and respiratory complications. ${ }^{9}$ Recently, the endoscopic endonasal approach for CVJ has been proposed as an alternative to the transoral route in some selective cases with advantages over the traditional route, but also with limitations. ${ }^{8-14}$

The advantages include the fact that this is a well-tolerated procedure by the patients, because it avoids soft or hard palate cut, reducing the risks of food or liquid regurgitation to the nose due to palate incontinence. Also, tongue manipulation or glossotomy is not necessary, avoiding tongue edema, necrosis or ventilator impairment. Prompt and safe orotracheal extubation after the surgery is allowed, decreasing pulmonary infection rates. ${ }^{7-14}$ The risk of dysphagia is decreased, when compared with the transoral approach, because the incision in the rhinopharynx muscle above the palatal line is minimized, with lower rates of injury to the neural plexus in the oropharyngeal wall, allowing prompt feeding after the surgery. ${ }^{11}$ Regarding infection, the risk is reduced compared with the transoral approach due to less contamination of the surgical field with saliva and oral bacterial flora. ${ }^{11-14}$

Furthermore, one of the main advantages is the angle of view of the odontoid in endoscopic approaches, allowing a caudal-cranial route and resection of anterior C1 arch if necessary. Some authors have advocated the preservation of the C1 anterior arch to keep the CVJ stable, ${ }^{15-17}$ but our cases received a complementary occipito-cervical fusion, and, in our opinion, the exposure is very restricted without removal of the $\mathrm{C} 1$ anterior arch. Also, opening the inferior portion of the sphenoidal sinus wall through an endosinusal route allows us to reach ventrally even in severe platybasia cases with high position of the dens. ${ }^{11,12}$ 
There are still limitations to this approach, which is challenging for neurosurgeons due to the depth of the route, the narrowness of the corridor, and the risk of major neurological disabilities related to the close relationship with the brainstem and upper spinal cord. Specifically, the endoscopic approach should be reserved for reference centers with welltrained surgeons. Furthermore, the position of the dens in relation to the palate is an important factor to take into consideration, as this approach is not considered a good option for dens located below the palate. ${ }^{18,19}$ Endoscopic endonasal odontoidectomy always lead to instability of cranio-cervical junction by damaging regional ligaments, and occipito-cervical fusion is recommended to prevent future problems. ${ }^{20}$

\section{Conclusion}

The endoscopic endonasal approach is a safe and effective option for decompression of the CVJ. There are some advantages and some limitations to this technique. Decrease of swallowing and respiratory issues are the main advantages. Position of dens in relation to the palate and learning curve are the major problems. Patient anatomy, disease characteristics and surgeon expertise must be considered when choosing the right approach. In our opinion, the transoral and the endoscopic endonasal approaches should be seen as complementary and not as alternatives.

Conflicts of Interest

The authors have no conflicts of interest to declare.

\section{References}

1 Apuzzo ML, Weiss MH, Heiden JS. Transoral exposure of the atlantoaxial region. Neurosurgery 1978;3(02):201-207

2 Shaha AR, Johnson R, Miller J, Milhorat T. Transoral-transpharyngeal approach to the upper cervical vertebrae. Am J Surg 1993; 166(04):336-340

3 Sakou T, Morizono Y, Morimoto N. Transoral atlantoaxial anterior decompression and fusion. Clin Orthop Relat Res 1984;(187): 134-138

4 Menezes AH, VanGilder JC. Transoral-transpharyngeal approach to the anterior craniocervical junction. Ten-year experience with 72 patients. J Neurosurg 1988;69(06):895-903

5 Seker A, Inoue K, Osawa S, Akakin A, Kilic T, Rhoton AL Jr. Comparison of endoscopic transnasal and transoral approaches to the craniovertebral junction. World Neurosurg 2010;74(06): 583-602

6 Alfieri A, Jho HD, Tschabitscher M. Endoscopic endonasal approach to the ventral cranio-cervical junction: anatomical study. Acta Neurochir (Wien) 2002;144(03):219-225, discussion 225

7 Kassam AB, Snyderman C, Gardner P, Carrau R, Spiro R. The expanded endonasal approach: a fully endoscopic transnasal approach and resection of the odontoid process: technical case report. Neurosurgery 2005;57(1, Suppl)E213, discussion E213

$8 \mathrm{Wu} \mathrm{JC}$, Mummaneni PV, El-Sayed IH. Diseases of the odontoid and craniovertebral junction with management by endoscopic approaches. Otolaryngol Clin North Am 2011;44(05):1029-1042

9 Crockard HA. Transoral surgery: some lessons learned. Br J Neurosurg 1995;9(03):283-293

10 Goldschlager T, Hartl R, Greenfield JP, et al. The endoscopic endonasal approach to the odontoid and its impact on early extubation and feeding. J Neurosurg 2014;31:1-8

11 Van Abel KM, Mallory GW, Kasperbauer JL, et al. Transnasal odontoid resection: is there an anatomic explanation for differing swallowing outcomes? Neurosurg Focus 2014;37(04):E16

12 Welch WC, Kassam A. Endoscopically assisted transoral-transpharyngeal approach to the craniovertebral junction. Neurosurgery 2003;52(06):1511-1512

13 Wolinsky JP, Sciubba DM, Suk I, Gokaslan ZL. Endoscopic imageguided odontoidectomy for decompression of basilar invagination via a standard anterior cervical approach. Technical note. J Neurosurg Spine 2007;6(02):184-191

14 Mummaneni PV, Haid RW. Transoral odontoidectomy. Neurosurgery 2005;56(05):1045-1050, discussion 1045-1050

15 Shetty A, Kumar A, Chacko A, Guthe S, Kini AR. Reduction techniques in the management of atlantoaxial subluxation. Indian J Orthop 2013;47(04):333-339

16 Magrini S, Pasquini E, Mazzatenta D, Mascari C, Galassi E, Frank G. Endoscopic endonasal odontoidectomy in a patient affected by Down syndrome: technical case report. Neurosurgery 2008;63 (02):E373-E374, discussion E374

17 El-Sayed IH, Wu JC, Dhillon N, Ames CP, Mummaneni P. The importance of platybasia and the palatine line in patient selection for endonasal surgery of the craniocervical junction: a radiographic study of 12 patients. World Neurosurg 2011;76(1-2):183-188, discussion 74-78

18 de Almeida JR, Zanation AM, Snyderman $\mathrm{CH}$, et al. Defining the nasopalatine line: the limit for endonasal surgery of the spine. Laryngoscope 2009;119(02):239-244

19 El-Sayed IH, Wu J-C, Ames CP, Balamurali G, Mummaneni PV. Combined transnasal and transoral endoscopic approaches to the craniovertebral junction. J Craniovertebr Junction Spine 2010;1 (01):44-48

20 Duntze J, Eap C, Kleiber JC, et al. Advantages and limitations of endoscopic endonasal odontoidectomy. A series of nine cases. Orthop Traumatol Surg Res 2014;100(07):775-778 